Jurnal Ekonomi Pembangunan

Volume 11, Nomor 2, Desember 2010, hlm.172-190

\title{
MENGAPA TERJADI GROWTH WITHOUT DEVELOPMENT DI PROVINSI KALIMANTAN TIMUR?
}

\author{
Mudrajad Kuncoro ${ }^{1}$ dan Ahmad Nafis Idris ${ }^{1}$ \\ ${ }^{1}$ Fakultas Ekonomika dan Bisnis Universitas Gadjah Mada \\ Jalan Sosio Humaniora Bulaksumur, Yogyakarta 55281, Indonesia, Telp: +62 274548510
}

Diterima 12 Oktober 2010/Disetujui 1 Nopember 2010

\begin{abstract}
This study attempts to examine to what extent growth without development has occured in East Kalimantan (Kaltim)? It will use several analyses, in particular regional typology based on economic growth and Gross Regional Domestic Product (GRDP), leading sectors and subsectors, location pattern of those leading sectors and subsectors, and the structural transformation. To analyse the effects of regional autonomy on Kaltim, the data used in this research are divided into two periods: before (1993-2000) and after regional autonomy (2001-2007). By using quantitative-descriptive analyses, our findings find that: first, miningexcavation has persisted to be the major leading sector in Kaltim. Second, leading subsectors in Kaltim comprise forestry, oil and gas, nonoil and gas industry, and wholesale-retail commerce. Third, the leading subsectors tend to despecialize in Kaltim during the implementation of regional autonomy. Fourth, structural transformation does not occur in all kabupaten/kota of Kaltim confirming that Kaltim is a good provincial example for growth without development.
\end{abstract}

Keywords: regional typology, location quotient, leading sector, structural transformation

\begin{abstract}
Abstrak: Penelitian ini berusaha mengetahui mengapa terjadi growth without development di Provinsi Kalimantan Timur. Beberapa alat analisis akan digunakan, khususnya yang berkaitan dengan tipologi daerah menurut struktur pertumbuhan ekonomi dan Produk Domestik Regional Bruto (PDRB), sektor dan subsektor unggulan, lokasi dari sektor dan subsektor unggulan, dan transformasi struktural. Untuk mengetahui pengaruh otonomi daerah (otda) terhadap perekonomian Provinsi Kaltim, periode penelitian dibagi ke dua periode waktu yakni periode sebelum otda (1993-2000) dan periode otda (2001-2007). Dengan menggunakan analisis deskriptif-kuantitatif, penelitian ini menemukan: pertama, pertambangan-penggalian tetap merupakan sektor unggulan utama di Kaltim, baik sebelum maupun selama otda berlangsung. Kedua, subsektor unggulan di Kaltim terdiri dari subsektor kehutanan, pertambangan minyak dan gas, industri pengolahan nonmigas, dan perdagangan besar-eceran. Ketiga, subsektor unggulan di Kaltim cenderung terdespesialisasi selama pelaksanaan otda. Keempat, transformasi struktural tidak terjadi di seluruh kabupaten/kota di Kaltim yang menegaskan bahwa Kaltim merupakan contoh provinsi yang mengalami gejala growth without development.
\end{abstract}

Kata kunci: tipologi daerah, location quotient, sektor unggulan, transformasi struktural

\section{PENDAHULUAN}

Kalimantan Timur (Kaltim) merupakan provinsi terluas kedua di Indonesia setelah Papua. Kaltim memiliki 9 kabupaten dan 4 kota, de- ngan Samarinda sebagai ibu kotanya. Provinsi ini terkenal kaya dengan sumberdaya alam (SDA) terutama minyak, gas bumi, batubara, emas, dan hasil-hasil hutan yang melimpah. Tidak mengherankan, Kaltim merupakan provinsi terkaya di Indonesia dengan Produk Do- 
mestik Regional Bruto (PDRB) per kapita pada tahun 2007 secara berturut-turut sebesar Rp36,5 juta dengan migas atau Rp19,4 juta tanpa migas. PDRB per kapita Kaltim tersebut terutama disumbang oleh lima kabupaten/kota, yakni Kutai Kartanegara, Bontang, Kutai Timur, Balikpapan, dan Samarinda dilihat dari PDRB migas. Jika dilihat dari PDRB nonmigas, maka lima kabupaten/kota penyumbang utama PDRB Kaltim adalah Kutai Timur, Samarinda, Balikpapan, Kutai Kartanegara, dan Pasir (lihat Gambar 1).

Kutai Kartanegara, Bontang, Kutai Timur, dan Pasir merupakan daerah-daerah yang memiliki SDA berlimpah, khususnya pertambangan-penggalian dan pertanian-peternakan-kehutanan. Ini tercermin dari besarnya kontribusi kedua sektor tersebut terhadap PDRB masingmasing daerah tersebut. Sementara, Samarinda dan Balikpapan merupakan daerah-daerah yang berperanan besar terhadap berkembangnya sektor sekunder (khususnya sektor industri pengolahan migas) dan tersier (khususnya sektor perdagangan-hotel-restoran, pengangkutankomunikasi, dan keuangan-persewaan-jasa perusahaan) di Kaltim.

Sayangnya, kekayaan alam Kaltim belum mampu meningkatkan kesejahteraan rakyat, sebagaimana tercermin dari masih banyaknya keluarga miskin, pengangguran, dan mening- katnya ketimpangan antardaerah. Ini setidaknya tercermin dari indeks eksploitasi ekonomi yang tetap tinggi selama 1996-2002 (lihat Tabel 1). Indeks ini menunjukkan "eksploitasi ekonomi" oleh pemerintah pusat atau investor asing, yang diestimasi dengan membandingkan PDRB per kapita dengan pengeluaran konsumsi per kapita (Mubyarto, 2005: 174). Kaltim termasuk 12 provinsi yang memiliki indeks eksploitasi ekonomi yang tinggi, bersama daerah kaya SDA lainnya seperti Riau, Sumatra Utara, dan Sumatra Selatan. Tingkat eksploitasi ekonomi Kaltim meningkat dari 89 pada tahun 1996 menjadi 90 pada tahun 2002. Pada tahun 2006, indeks tersebut mengalami sedikit penurunan hingga mencapai 86. Artinya tiap PDRB naik sebesar 100, proporsi yang dinikmati rakyat Kaltim hanya 11 persen tahun 1996, 10 persen tahun 2002, dan 14 persen tahun 2006. Hal ini juga menunjukkan bahwa income gap antara kaya dan miskin sangat tinggi yang berdampak timbulnya rasa ketidakadilan dan kecemburuan sosial antarmasyarakat.

Pertanyaan mendasar yang muncul adalah apakah Kaltim merupakan contoh provinsi yang mengalami "growth without development" (pertumbuhan tanpa diikuti dengan pembangunan)? Benarkah hal ini disebabkan oleh tidak terjadinya transformasi struktural di masing-masing kabupaten/kota Kaltim? Artikel

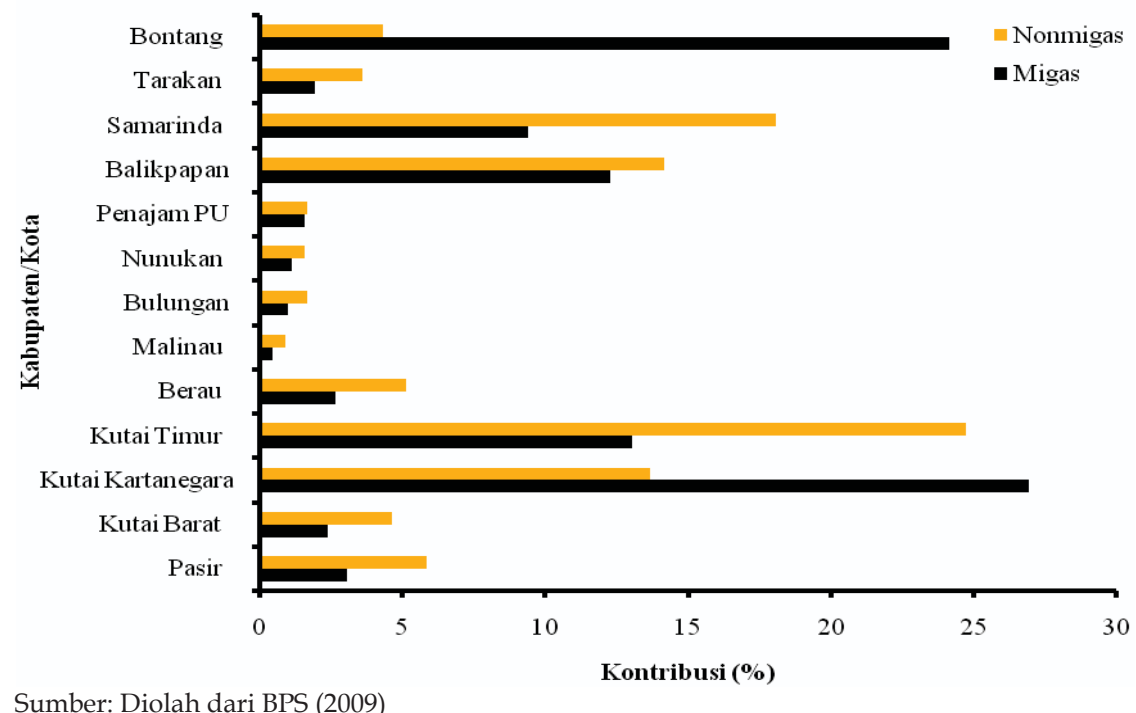

Gambar 1. Kontribusi PDRB Kabupaten/Kota terhadap PDRB Provinsi Kaltim Tahun 2007 
Tabel 1. PDRB Per Kapita, Konsumsi Per Kapita, dan Tingkat Eksploitasi Ekonomi Provinsi Indonesia, 1996-2006

\begin{tabular}{|c|c|c|c|c|c|}
\hline \multirow{2}{*}{ Provinsi } & \multirow{2}{*}{$\begin{array}{l}\text { PDRB per Kapita } \\
\text { (ribu Rp) }\end{array}$} & \multirow{2}{*}{$\begin{array}{l}\text { Konsumsi per Kapita } \\
\text { (ribu Rp) }\end{array}$} & \multicolumn{3}{|c|}{ Indeks Eksploitasi (\%) } \\
\hline & & & 1996 & 2002 & 2006 \\
\hline NAD & 8.998 & 3.395 & 81 & Tda & 62 \\
\hline Sumatera Utara & 7.405 & 1.535 & 68 & 69 & 79 \\
\hline Sumatera Barat & 6.703 & 2.857 & 59 & 60 & 57 \\
\hline Riau & 17.677 & 2.197 & 84 & 76 & 88 \\
\hline Jambi & 4.997 & 2.550 & 54 & 59 & 49 \\
\hline Sumatera Selatan & 7.602 & 1.303 & 67 & 70 & 83 \\
\hline Bengkulu & 4.205 & 3.322 & 53 & 49 & 21 \\
\hline Lampung & 4.292 & 919 & 55 & 56 & 79 \\
\hline Bangka-Belitung & 8.527 & 5.212 & Tda & 66 & 39 \\
\hline Kepulauan Riau & 24.583 & 4.517 & Tda & Tda & 82 \\
\hline DKI Jakarta & 35.024 & 2.007 & 78 & 81 & 94 \\
\hline Jawa Barat & 6.526 & 613 & 55 & 56 & 91 \\
\hline Jawa Tengah & 4.686 & 703 & 62 & 58 & 85 \\
\hline DIY & 5.196 & 887 & 58 & 47 & 83 \\
\hline Jawa Timur & 7.433 & 726 & 69 & 65 & 90 \\
\hline Banten & 6.686 & 733 & Tda & 54 & 89 \\
\hline Bali & 6.494 & 2.407 & 66 & 47 & 63 \\
\hline NTB & 3.686 & 1.208 & 48 & 52 & 67 \\
\hline NTT & 2.395 & 1.802 & 46 & 29 & 25 \\
\hline Kalimantan Barat & 6.035 & 1.990 & 68 & 57 & 67 \\
\hline Kalimantan Tengah & 7.625 & 4.933 & 73 & 65 & 35 \\
\hline Kalimantan Selatan & 7.357 & 2.634 & 65 & 62 & 64 \\
\hline Kalimantan Timur & 33.208 & 4.496 & 89 & 90 & 86 \\
\hline Sulawesi Utara & 6.271 & 2.760 & 62 & 51 & 56 \\
\hline Sulawesi Tengah & 5.437 & 2.516 & 54 & 58 & 54 \\
\hline Sulawesi Selatan & 5.122 & 1.937 & 55 & 54 & 62 \\
\hline Sulawesi Tenggara & 4.337 & 3.288 & 52 & 53 & 24 \\
\hline Sulawesi Barat & 3.373 & 3.083 & Tda & Tda & 9 \\
\hline Irian Jaya Barat & 8.382 & 3.813 & Tda & Tda & 55 \\
\hline Papua & 9.595 & 3.327 & 82 & Tda & 65 \\
\hline
\end{tabular}

$\mathrm{Tda}=$ tidak tersedia data

Sumber: Mubyarto (2005: 175); Kuncoro (2008); Diolah dari Susenas 2006 (BPS, 2006)

ini akan mencoba menjawab pertanyaan ini.

Tipologi Kabupaten/Kota di Kaltim. Untuk mengetahui karakteristik dan posisi masing-masing kabupaten/kota di Kaltim, berikut ini akan digunakan analisis tipologi daerah. Analisis tipologi daerah ${ }^{1}$ disusun berdasarkan

1 Alat analisis tipologi daerah digunakan untuk mengetahui gambaran tentang pola dan struktur pertumbuhan ekonomi masing-masing daerah. High growth and high income adalah daerah yang memiliki tingkat pertumbuhan ekonomi dan pendapatan per kapita yang lebih tinggi dibanding rata-rata seluruh kabupaten/kota. High income but low growth adalah daerah yang memiliki pendapatan per kapita lebih tinggi, tetapi tingkat pertumbuhan ekonominya lebih rendah dibanding rata-rata seluruh kabupaten/kota. High growth but low income adalah daerah yang memiliki tingkat pertumbuhan tinggi, tetapi tingkat pen- tingkat pertumbuhan ekonomi dan PDRB per kapita (Hill, 1989; Kuncoro, 1996). Dengan analisis ini, daerah kabupaten/kota di Kaltim dapat digolongkan ke dalam empat kelompok, yaitu (1) daerah cepat maju dan cepat tumbuh (high growth and high income); (2) daerah maju tapi tertekan (high income but low growth); (3) daerah berkembang cepat (high growth but low

dapatan per kapita lebih rendah dibanding rata-rata kabupaten/kota di Indonesia. Low growth and low income adalah daerah yang memiliki tingkat pertumbuhan ekonomi dan pendapatan per kapita yang lebih rendah dibanding ratarata kabupaten/kota di Indonesia. Disebut "tinggi" apabila indikator di suatu kabupaten/kota lebih tinggi dibandingkan rata-rata seluruh kabupaten/kota; digolongkan "rendah" apabila indikator di suatu kabupaten/kota lebih rendah dibandingkan rata-rata seluruh kabupaten/kota. 
(a) Sebelum Otda (1993-2000)

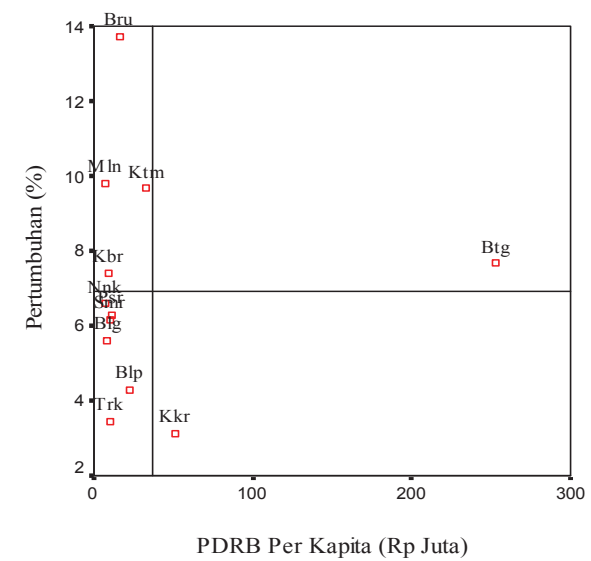

(b) Selama Otda (2001-2007)

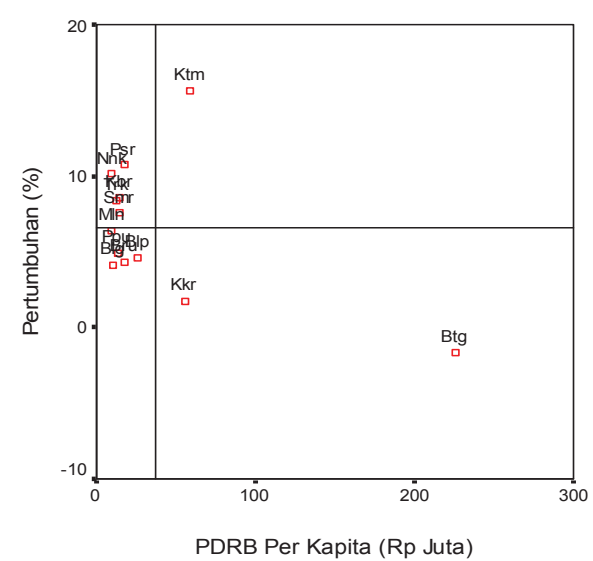

Sumber: Diolah dari BPS (2009); BPS Provinsi Kaltim (2008)

\section{Gambar 2. Tipologi Daerah Kabupaten/Kota di Kaltim Menurut PDRB Migas} Sebelum (1993-2000) dan Selama Otda (2001-2007)

income); dan (4) daerah relatif tertinggal (low growth and low income).

Penerapan otonomi daerah sejak tahun 2001 memberikan dampak positif terhadap tingkat pertumbuhan ekonomi dan PDRB per kapita. Meskipun tingkat pertumbuhan ekonomi rata-rata selama otonomi daerah (2001-2007) sebesar 6,58 persen lebih rendah dibandingkan sebelum otonomi daerah (1993-2000) sebesar 6,98 persen, PDRB per kapita mengalami peningkatan yang cukup signifikan. PDRB per kapita rata-rata meningkat dari Rp36,63 juta sebelum otonomi daerah menjadi Rp37,23 juta selama otonomi daerah (lihat Gambar 2a dan 2b).

Di samping itu, jumlah kabupaten/kota yang masuk dalam kelompok daerah relatif tertinggal mengalami penurunan semenjak otda diterapkan di Kaltim. Sebelum otda, jumlah daerah relatif tertinggal berjumlah 6 kabupaten/kota. Kabupaten/kota tersebut adalah Pasir (Psr), Bulungan (Blg), Nunukan (Nnk), Balikpapan (Blp), Samarinda (Smr), dan Tarakan (Trk). Selama otda daerah relatif tertinggal menurun menjadi 5 kabupaten/kota. Kabupaten/kota tersebut adalah Berau (Bru), Malinau (Mln), Bulungan (Blg), Penajam Pasir Utara (Ppu), dan Balikpapan (Blp). Ppu yang dibentuk setelah otonomi daerah masuk dalam kategori daerah relatif tertinggal. Dengan demikian, pelaksanaan otonomi daerah di Kaltim mampu mengurangi dua daerah yang tadinya tergolong daerah relatif tertinggal.

Struktur ekonomi Provinsi Kaltim amat mengandalkan sektor pertambangan-penggalian, perdagangan-hotel-restoran, pertanian-peternakan-kehutanan, dan industri pengolahan. Keempat sektor tersebut merupakan kontributor terbesar dalam pembentukan 3a dan 3b). Baik berdasarkan PDRB nonmigas maupun migas selama 1993-2007, komposisi kontribusi sektoral PDRB Kaltim mengalami perubahan. Sektor perdagangan-hotel-restoran merupakan kontributor terbesar PDRB nonmigas pada tahun 1993. Pada tahun 2007, posisi tersebut digantikan oleh sektor pertambangan-penggalian. Demikian juga dengan PDRB migas, posisi sektor industri pengolahan sebagai kontributor terbesar pada tahun 1993 digantikan oleh sektor pertambangan-penggalian pada tahun 2007. Kecenderungan peningkatan pangsa sektor pertambangan-penggalian terhadap PDRB migasnonmigas telah terlihat sejak tahun 2000. Dengan demikian, struktur ekonomi Kaltim baik berdasarkan PDRB migas-nonmigas pada tahun 2007 sangat mengandalkan sektor pertambangan-penggalian. 
(a ) Nonmigas

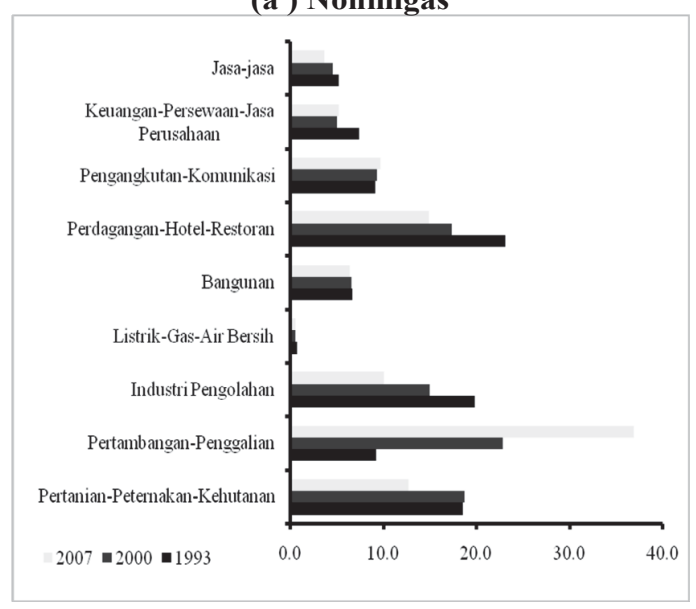

Sumber: Diolah dari BPS (2009) (b ) Migas

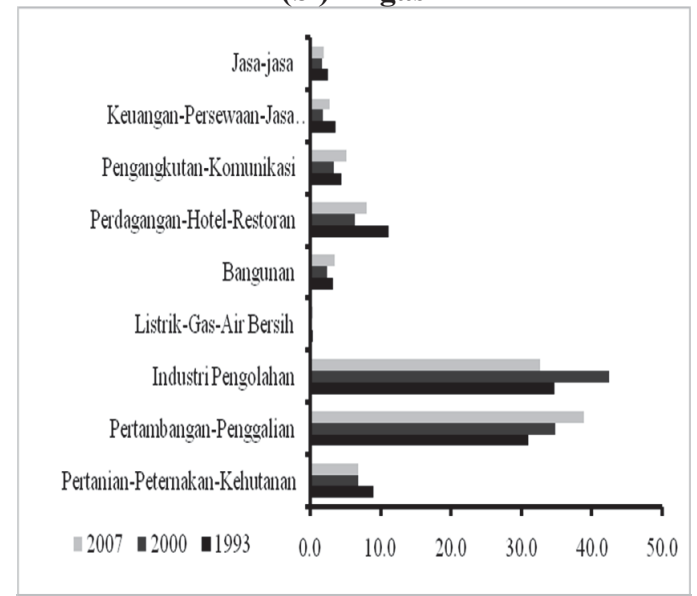

Gambar 3. Kontribusi Sektoral PDRB di Provinsi Kaltim, 1993-2007

\section{METODE PENELITIAN}

Untuk dapat eksis dalam persaingan global, maka suatu negara mutlak harus memiliki daya saing. Daya saing negara merupakan cerminan dari daya saing di tingkat daerah. Suatu daerah memiliki reaksi yang berbeda-beda dalam menyikapi dampak dari fenomena globalisasi. Hal tersebut akan mempengaruhi posisi tawar masing-masing daerah dalam kompetisi yang semakin ketat. Ini menunjukkan betapa pentingnya kemampuan daerah dalam meningkatkan daya saingnya sebagai penentu keberhasilan pembangunan di daerah tersebut. Salah satu wujud daya saing daerah adalah kepemilikan daerah tersebut atas satu atau beberapa sektor/subsektor unggulan yang merupakan basis ekonomi daerah tersebut.

Kajian dan penelitian tentang sektor dan subsektor yang menjadi unggulan di suatu daerah telah banyak dilakukan. Hal tersebut tentu saja merupakan kecenderungan yang baik mengingat daya saing suatu negara hanya dapat ditentukan dan ditingkatkan ketika sektor/subsektor unggulan daerah telah diketahui. Sayangnya, kajian-kajian atau penelitian-penelitian yang sudah ada tersebut hanya sebatas mengidentifikasi sektor/subsektor unggulan tanpa melihat adanya kecenderungan peningkatan (spesialisasi) atau penurunan (despesialisasi) terhadap sektor/subsektor unggulan ter- sebut selama periode waktu yang lama.

Artikel ini di samping berusaha mengidentifikasi sektor dan subsektor unggulan dengan studi kasus Provinsi Kalimantan Timur (Kaltim), juga mencoba mengetahui kecenderungan spesialisasi atau despesialisasi atas sektor dan subsektor unggulan tersebut selama periode waktu yang cukup lama yakni 1993-2007. Pengetahuan tentang spesialisasi atau despesialisasi dapat memberikan informasi berharga mengenai adanya fokus atau ketidakfokusan pada sektor dan subsektor unggulan di daerah. Informasi tersebut sangat bermanfaat bagi evaluasi dan penyusunan strategi peningkatan daya saing daerah yang berikutnya. Di samping itu, penelitian ini juga berusaha memberikan informasi mengenai terjadi-tidaknya transformasi struktural dalam perekonomian Kaltim. Transformasi struktural umumnya tidak terjadi pada daerah-daerah yang memiliki kekayaan berlimpah terutama pada pertambangan-penggalian. Analisis tentang transformasi struktural ini penting karena bisa jadi daerah-daerah yang kaya sumberdaya alam tersebut memang sengaja tidak ingin memperkenalkan industrialisasi dalam perekonomiannya.

\section{Data}

Data yang dipakai adalah data Produk Domestik Regional Bruto (PDRB) menurut sektor ekonomi yang dipublikasikan oleh Badan Pusat 
Statistik (BPS). Data tersebut merupakan data sekunder dengan periode amatan selama 19932007. Periode amatan tersebut dibagi ke dalam dua kelompok interval, yakni 1993-2000 dan 2001-2007. Pembagian tersebut ditujukan untuk mengetahui pengaruh pelaksanaan otonomi daerah terhadap berbagai variabel yang berusaha diketahui dalam penelitian ini. Lingkup sektor dan subsektor ekonomi yang menjadi kajian pada penelitian ini terdiri dari 9 sektor dan 26 subsektor ekonomi atau lapangan usaha (lihat Tabel 2).

\section{Indikator Sektor dan Subsektor Unggulan}

Indeks Location Quotient (LQ) merupakan ukuran yang dipakai untuk mengukur sektor dan subsektor unggulan. Secara sederhana, indeks LQ, yang juga dikenal sebagai indeks Static LQ (SLQ), diformulasikan sebagai berikut (Bendavid-Val, 1997):

$$
S L Q_{i K}=\frac{X_{i K} / \sum X_{i K}}{X_{i I} / \sum X_{i I}}
$$

Untuk dapat mengakomodasi faktor laju pertumbuhan sektor/subsektor dari waktu ke waktu, maka SLQ dimodifikasi menjadi Dynamic LQ (DLQ). Secara sederhana, indeks DLQ diukur dengan formulasi sebagai berikut (Kuncoro, et al., 2005):

$D L Q_{i K}=\left[\frac{\left(1+g_{i K}\right) /\left(1+g_{K}\right)}{(1+G i I) /(1+G I)}\right]^{t}=\frac{I P P S_{i K}}{I P P S_{i I}}$

Penggunaan SLQ dan DLQ dalam analisis sektor atau subsektor unggulan memiliki beberapa kelemahan. Nilai SLQ berkisar antara 0 sampai positif tak terhingga, dengan 1 sebagai

Tabel 2. Sektor dan Subsektor Ekonomi dalam PDRB

\begin{tabular}{ll}
\hline \multicolumn{1}{c}{ Sektor } & \multicolumn{1}{c}{ Subsektor } \\
\hline 1. Pertanian, Peternakan, dan Kehutanan & 1. Tanaman Bahan Makanan \\
2. Pertambangan dan Penggalian & 2. Tanaman Perkebunan \\
3. Industri Pengolahan & 3. Peternakan dan Hasil-hasilnya \\
4. Listrik, Gas, dan Air Bersih & 4. Kehutanan \\
5. Bangunan & 5. Perikanan \\
6. Perdagangan, Hotel, dan Restoran & 6. Minyak dan Gas Bumi \\
7. Pengangkutan dan Komunikasi & 7. Pertambangan tanpa Migas \\
8. Keuangan, Persewaan, dan Jasa Perusahaan & 8. Penggalian \\
9. Jasa-jasa & 9. Industri Migas \\
& 10. Industri Tanpa Migas \\
& 11. L i s t r i k \\
12. Gas \\
13. Air Bersih \\
14. Bangunan \\
15. Perdagangan Besar dan Eceran \\
16. Hotel \\
17. Restoran \\
18. Pengangkutan \\
19. Komunikasi \\
20. Bank \\
21. Lembaga Keuangan tanpa Bank \\
22. Jasa Penunjang Keuangan \\
23. Sewa Bangunan \\
24. Jasa Perusahaan \\
25. Jasa Pemerintahan Umum \\
26. Jasa Swasta \\
\hline
\end{tabular}

Sumber: BPS (2009) 
nilai tengah. Kelemahan dari indeks SLQ/DLQ terletak pada pembobotan yang berbeda antara nilai SLQ/DLQ di bawah 1 dengan nilai SLQ/DLQ di atas 1. Pembobotan pada nilai SLQ/DLQ di atas 1 lebih besar daripada nilai SLQ/DLQ di bawah 1. Dengan kata lain, pembobotan yang tidak sama tersebut menyebabkan terjadinya ketidaksimetrisan pada indeks SLQ/DLQ.

Sebagai alternatifnya, penelitian ini akan memperkenalkan dan menggunakan Static Symmetric LQ (SSLQ) dan Dynamic Symmetric LQ (DSLQ) sebagai alternatif yang lebih baik dalam aplikasi model ekonometrika. Pengonversian SLQ dan DLQ ke dalam bentuk simetrik yakni SSLQ dan DSLQ ditujukan agar diperoleh indeks yang nilainya berkisar antara 1 sampai 1. SSLQ dan DSLQ secara sederhana merupakan transformasi dari indeks SLQ dan DLQ. Nilai SSLQ dan DSLQ diperoleh dengan melakukan transformasi sebagai berikut (Dalum, et al. 1998; Laursen, 1998; dan Widodo, 2009)2:

$$
\begin{aligned}
& S S L Q_{i}=\frac{S L Q_{i}-1}{S L Q_{i}+1} \\
& D S L Q_{i}=\frac{D L Q_{i}-1}{D L Q_{i}+1}
\end{aligned}
$$

Karena dimungkinkannya DLQ bernilai negatif, maka transformasi DLQ menjadi DSLQ untuk DLQ yang bernilai negatif adalah sebagai berikut:

2 Metode analisis LQ dalam kajian ekonomi regional pada dasarnya tidak berbeda dengan konsep Revealed Comparative Advantage (RCA) dalam kajian ekonomi internasional. Kedua alat analisis tersebut sama-sama digunakan untuk mengetahui komoditas (sektor atau subsektor) unggulan atau berdaya saing di suatu wilayah. Perbedaannya adalah bahwa RCA digunakan untuk lingkup yang lebih luas, yakni negara dan dunia. Dalum, Laursen, dan Widodo dalam penelitiannya mencoba mensimetriskan indeks RCA menjadi Revealed Symmetric Comparative Advantage (RSCA). RSCA diperoleh dengan melakukan transformasi sederhana terhadap indeks RCA. Proses transformasinya sebagai berikut:

$$
R S C A_{j}=\left(R C A_{j}-1\right) /\left(R C A_{j}+1\right)
$$

di mana: $\mathrm{RSCA}_{\mathrm{ij}}$ adalah Revealed Symmetric Comparative Advantage negara i pada produk $\mathrm{j}$; dan RCAij adalah Revealed Comparative Advantage negara i pada produk j.
$D S L Q_{i}=\frac{D L Q_{i}+1}{D L Q_{i}-1}$

Untuk DLQ yang bernilai lebih besar atau sama dengan minus 1 (DLQ $\geq-1$ ), maka nilai DSLQ dapat diperoleh dengan cukup melakukan transformasi seperti formula 5. Namun, jika DLQ bernilai lebih kecil dari minus 1 (DLQ<-1), maka nilai DSLQ positif yang didapat dengan menerapkan formula 5 tersebut harus dikalikan terlebih dahulu dengan minus 1 sehingga diperoleh nilai DSLQ yang minus kembali.

Gabungan antara nilai SLQ dan DLQ atau SSLQ dan DSLQ dijadikan kriteria dalam menentukan apakah sektor atau subsektor tertentu tergolong unggulan, prospektif, andalan atau tertinggal (lihat Tabel 3). Untuk menguji bahwa hasil kesimpulan yang memakai indeks SLQDLQ tidak berbeda dengan indeks SSLQ-DSLQ, maka digunakan indeks Spearman's Rank Correlation $^{3}$.

Tabel 3. Klasifikasi Sektor-Subsektor Berdasar kan Gabungan Nilai SLQ dan DLQ atau SSLQ dan DSLQ

\begin{tabular}{ccc}
\hline Kriteria & $\begin{array}{c}\text { SLQ }<\mathbf{1} \\
\text { atau } \\
\text { SSLQ }<\mathbf{0}\end{array}$ & $\begin{array}{c}\text { SLQ }>\mathbf{1} \\
\text { atau } \\
\text { SSLQ }>\mathbf{0}\end{array}$ \\
\hline $\begin{array}{l}\text { DLQ }>1 \text { atau } \\
\text { DSLQ }>0\end{array}$ & andalan & unggulan \\
DLQ $<1$ atau & tertinggal & prospektif \\
DSLQ $<0$ & & \\
\hline
\end{tabular}

Sumber: Kuncoro, et al. (2009)

3 Spearman's rank correlation atau yang sering disebut dengan korelasi tata jenjang digunakan untuk jenis data Ordinal, baik variabel X maupun Y. Korelasi Spearman dihitung dengan menggunakan persamaan sebagai berikut: $r_{s}=1-\frac{6 \sum_{i=1}^{n} d_{i}^{2}}{n\left(n^{2}-1\right)}$

di mana: $\mathrm{r}_{\mathrm{s}}$ adalah korelasi Spearman (rho); $\mathrm{n}$ adalah jumlah kasus atau sampel; dan $\mathrm{d}_{\mathrm{i}}$ adalah selisih ranking antara variabel X dan Y untuk tiap-tiap kasus. 


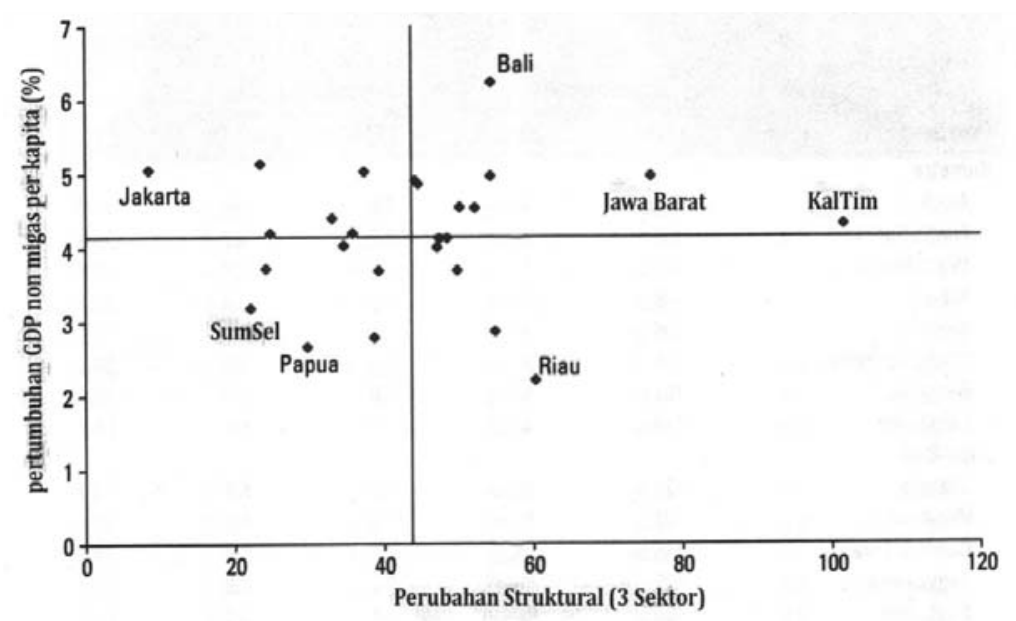

Sumber: Hill et al. (2009)

Gambar 4. Perubahan Struktural dan Pertumbuhan di Indonesia, 1975-2004

\section{Indeks Transformasi Struktural}

Geografi aktivitas ekonomi di Indonesia dapat dilihat melalui hubungan antara perubahan struktural dengan pertumbuhan Indonesia. Secara teoritis seharusnya terdapat hubungan positif antara pertumbuhan ekonomi dengan kecepatan perubahan struktural. Perubahan Struktural diukur dengan Indeks Transformasi Struktural (ITS), yaitu

$$
\begin{aligned}
\text { ITS }= & \sum_{\mathrm{i}} \mid \text { share }_{\mathrm{i}, 01}-\text { share }_{\mathrm{i}, 00} \mid ; \mathrm{yi}=\{\text { pertanian, } \\
& \text { industri nonmigas, jasa }\}
\end{aligned}
$$

dimana share $_{i, 01}$ adalah rata-rata sumbangan sektor i pada periode otonomi daerah (20012007); share $_{i, 00}$ adalah rata-rata sumbangan sektor i pada periode sebelum otda (1993-2000). Sektor i dikelompokkan menjadi tiga sektor saja yaitu pertanian, industri nonmigas, dan jasa.

Hasil analisis Hill, et al. (2009), sebagaimana disajikan Gambar 4, menunjukkan adanya korelasi yang lemah antara pertumbuhan dan perubahan struktural pada periode 1975-2004. Perubahan struktural tercepat terjadi di beberapa provinsi, antara lain: Kalimantan Timur (mencerminkan terjadinya resource boom dan spill over), Jawa Barat (majunya industrialisasi), Riau (resource boom dan dampak dari Singapura), Maluku, Bali (pariwisata dan industrialisasi), dan Jawa Tengah. Perubahan struktural cenderung lambat pada provinsi-provinsi dengan basis sektor pertanian. Tampak Kalimantan, Jawa Barat, dan Bali mengalami perubahan struktural diikuti dengan persentase pertumbuhan PDRB nonmigas per kapita yang tinggi.

\section{HASIL DAN PEMBAHASAN}

\section{Analisis Sektor dan Subsektor Unggulan}

Hasil analisis dengan menggunakan location quotient (LQ), baik dengan static LQ (SLQ) maupun dynamic LQ (DLQ) adalah sama dengan hasil analisis ketika indeks LQ tersebut dibuat simetris (symmetric LQ), baik static symmetric LQ (SSLQ) maupun dynamic symmetric LQ (DSLQ). Tidak berbedanya hasil analisis indeks SLQDLQ dengan SSLQ-DSLQ ditunjukkan oleh nilai Spearman's rank correlation sebesar $1^{4}$, yang berarti bahwa hasil analisis kedua indeks yakni SLQ-DLQ dan SSLQ-DSLQ adalah identik atau

\footnotetext{
Spearman' rank correlation antara klasifikasi sektor/subsektor menurut SLQ dan DLQ dengan klasifikasi sektor/ subsektor menurut SSLQ dan DSLQ adalah 1. Hasil tersebut menunjukkan bahwa klasifikasi berdasarkan dua indeks tersebut identik atau sama persis.
}

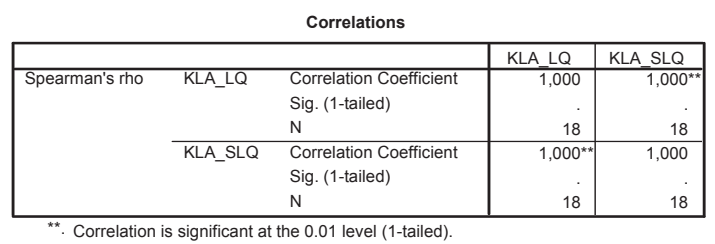


Tabel 4. Klasifikasi Sektor Usaha Berdasarkan Nilai SLQ dan DLQ, 1993-2000 (Sebelum Otda) dan 2001-2007 (Selama Otda)

\begin{tabular}{lcccc}
\hline \multirow{2}{*}{ Sektor Ekonomi } & \multicolumn{2}{c}{$\begin{array}{c}\text { 1993-2000 } \\
\text { (Sebelum Otda) }\end{array}$} & \multicolumn{2}{c}{$\begin{array}{c}\text { 2001-2007 } \\
\text { (Selama Otda) }\end{array}$} \\
& SLQ & DLQ & SLQ & DLQ \\
\hline Pertanian-Peternakan-Kehutanan & 0,55 & $-10,25$ & 0,42 & 1,37 \\
Pertambangan-Penggalian & 2,67 & 3,25 & 3,95 & 2,53 \\
Industri Pengolahan & 1,42 & 0,57 & 1,45 & $-0,30$ \\
Listrik-Gas-Air Bersih & 0,46 & 0,94 & 0,24 & 2,31 \\
Bangunan & 0,58 & 0,27 & 0,55 & 2,26 \\
Perdagangan-Hotel-Restoran & 0,93 & 0,93 & 0,36 & 1,58 \\
Pengangkutan-Komunikasi & 0,87 & 2,47 & 0,70 & 1,80 \\
Keuangan-Persewaan-Jasa Perusahaan & 0,53 & 0,67 & 0,26 & 2,84 \\
Jasa-jasa & 0,34 & 3,20 & 0,21 & 1,58 \\
\hline
\end{tabular}

Sumber: Diolah dari BPS (2009)

sama persis (lihat Tabel 4 dan Tabel 5).

Hasil analisis sebagaimana ditunjukkan oleh nilai kedua indeks (LQ dan symmetric LQ) menunjukkan bahwa sektor unggulan di Kaltim adalah sektor pertambangan-penggalian. Sektor pertambangan-penggalian tetap merupakan sektor unggulan di Kaltim, baik sebelum maupun selama otda berlangsung. Meskipun penerapan otda di Kalt im tidak berdampak pada terjadinya perubahan sektor unggulan, jumlah sektor yang masuk dalam kategori andalan mengalami peningkatan secara signifikan dan tiadanya sektor yang berkategori tertinggal (lihat Tabel 6 dan Tabel 7). Dengan kata lain, pelaksanaan otda berpengaruh positif terhadap klasifikasi sektoral di Kaltim, khususnya terhadap sektor-sektor yang tergolong tertinggal pada periode sebelum otda. Sebelum otda, Kaltim memiliki banyak sektor ekonomi yang tergolong sektor tertinggal, yakni pertanian-peternakan-kehutanan, listrik-gas-air bersih, bangunan, perdagangan-hotel-restoran, dan keuangan-persewaan-jasa perusahaan. Sementara, sektor andalan di Kaltim sebelum otda berlangsung adalah pengangkutan-komunikasi dan jasa-jasa. Ketika otda berlangsung yang dimulai dari tahun 2001, Kaltim sudah tidak lagi memiliki sektor-sektor tertinggal. Sektor-sektor tertinggal tersebut pada masa otda masuk dalam kategori sektor-sektor andalan.

Sektor unggulan dan prospektif di Kaltim tidak mengalami perubahan, baik sebelum maupun ketika otda berlangsung. Sektor unggulan dan prospektif di Kaltim selama dua periode tersebut secara berturut-turut adalah sektor pertambangan-penggalian dan industri pe-

Tabel 5. Klasifikasi Sektor Usaha Berdasarkan Nilai SSLQ dan DSLQ, 1993-2000 (Sebelum Otda) dan 2001-2007 (Selama Otda)

\begin{tabular}{lcccc}
\hline \multicolumn{1}{c}{ Sektor Ekonomi } & 1993-2000 (Sebelum Otda) & 2001-2007 (Selama Otda) \\
& SSLQ & DSLQ & SSLQ & DSLQ \\
\hline Pertanian-Peternakan-Kehutanan & $-0,29$ & $-0,82$ & $-0,41$ & 0,15 \\
Pertambangan-Penggalian & 0,46 & 0,53 & 0,60 & 0,43 \\
Industri Pengolahan & 0,17 & $-0,27$ & 0,18 & $-0,54$ \\
Listrik-Gas-Air Bersih & $-0,37$ & $-0,03$ & $-0,61$ & 0,40 \\
Bangunan & $-0,27$ & $-0,57$ & $-0,29$ & 0,39 \\
Perdagangan-Hotel-Restoran & $-0,04$ & $-0,03$ & $-0,47$ & 0,22 \\
Pengangkutan-Komunikasi & $-0,07$ & 0,42 & $-0,18$ & 0,29 \\
Keuangan-Persewaan-Jasa Perusahaan & $-0,30$ & $-0,20$ & $-0,59$ & 0,48 \\
Jasa-jasa & $-0,50$ & 0,52 & $-0,66$ & 0,23 \\
\hline
\end{tabular}

Sumber: Diolah dari BPS (2009) 


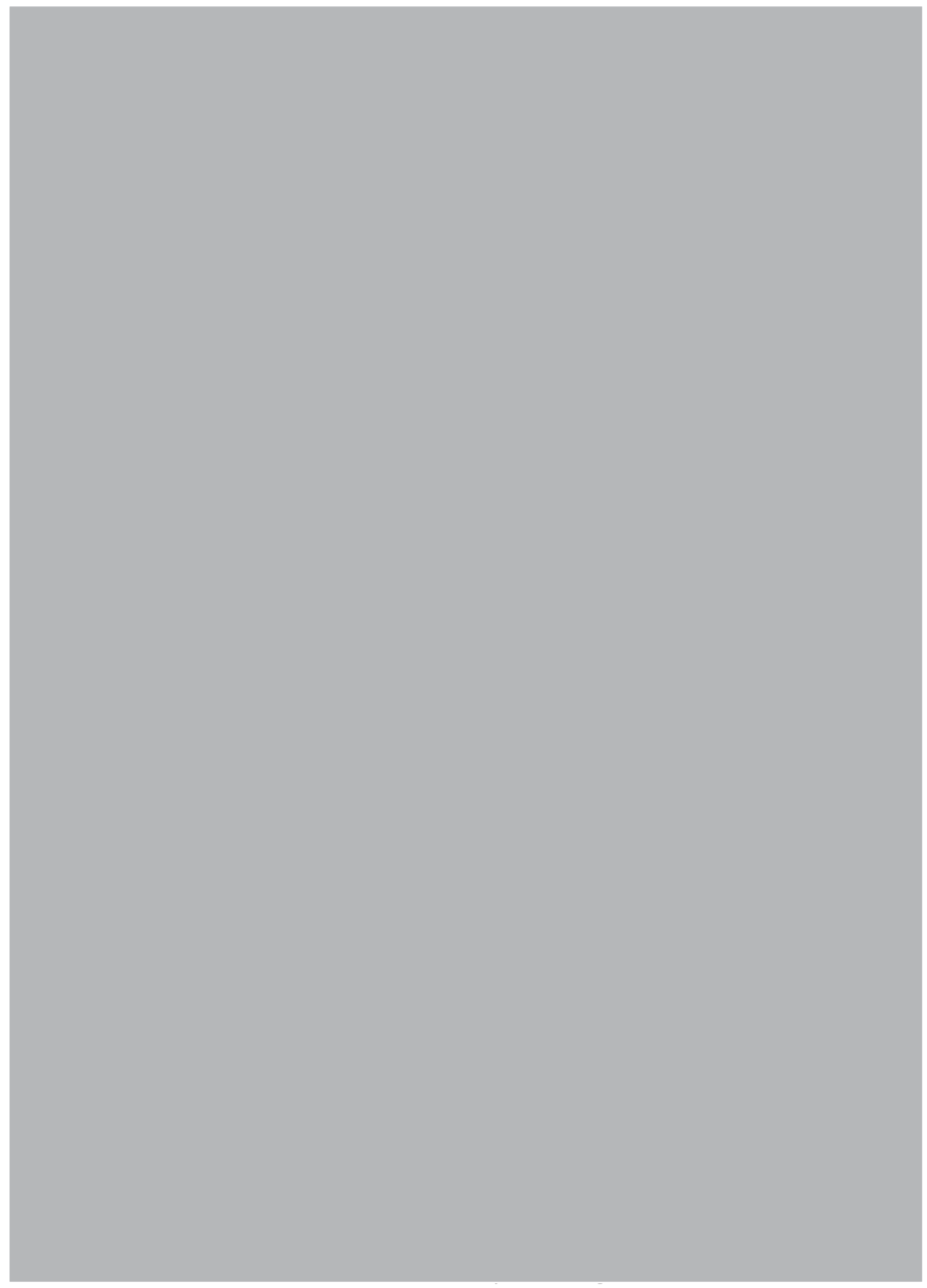


Tabel 8. Klasifikasi Subsektor UsahaMenurut SSLQ dan DSLQ 1993-2000 (Sebelum Otda)

\begin{tabular}{lll}
\hline Kriteria & \multicolumn{1}{c}{ SSLQ $<$ 0 } & \multicolumn{1}{c}{ SSLQ $>\mathbf{0}$} \\
\hline & Subsektor Andalan: & Subsektor Unggulan: \\
& Tanaman Bahan Makanan; & Kehutanan; \\
& Tanaman Perkebunan; & Minyak dan Gas Bumi; \\
& Peternakan dan Hasil-hasilnya; & Perdagangan Besar dan \\
& Air Bersih; Hotel; & Eceran \\
& Lembaga Keuangan tanpa Bank; & \\
& Jasa Penunjang Keuangan; & \\
SSLQ $>0$ & Sewa Bangunan; & \\
& Pemerintahan Umum & \\
& Subsektor Tertinggal: & Subsektor Prospektif: \\
& Perikanan; & Pertambangan tanpa \\
& Penggalian; & Migas; \\
& Industri Tanpa Migas; & Industri Migas \\
& Listrik; Bangunan; & \\
& Restoran; Pengangkutan; & \\
& Komunikasi; Bank; & \\
& Jasa Perusahaan; & \\
& Swasta & \\
\hline
\end{tabular}

Sumber: Diolah dari BPS (2009)

Tabel 9. Klasifikasi Subsektor Usaha Menurut SSLQ dan DSLQ 2001-2007 (Selama Otda)

\begin{tabular}{llr}
\hline Kriteria & \multicolumn{1}{c}{ SSLQ $<$ 0 } & \multicolumn{1}{c}{ SSLQ $>\mathbf{0}$} \\
\hline & Subsektor Andalan: & Subsektor Unggulan: \\
& Tanaman Bahan Makanan; & Minyak dan Gas Bumi; \\
& Tanaman Perkebunan; & Pertambangan tanpa \\
& Peternakan dan Hasil-hasilnya; & Migas; \\
& Perikanan; Penggalian; & Industri Migas; \\
& Industri Tanpa Migas; & \\
& Listrik; Air Bersih; & \\
& Bangunan; Hotel & \\
& Perdagangan Besar dan Eceran; \\
& Restoran; Pengangkutan; & \\
& Komunikasi; Bank; & \\
LSLQ $>0$ & Lembaga Keuangan tanpa Bank; & \\
& Jasa Penunjang Keuangan; & \\
& Sewa Bangunan; & \\
& Jasa Perusahaan; & \\
& Pemerintahan Umum; Swasta & \\
& Subsektor Tertinggal: & Kehutanan \\
\hline
\end{tabular}

Sumber: Diolah dari BPS (2009)

dari total tiga belas kabupaten/kota yang ada di Kaltim merupakan daerah pertambangan dan penggalian. Delapan kabupaten tersebut adalah Kabupaten Pasir, Kutai Barat, Kutai Kartanegara, Kutai Timur, Berau, Malinau, Bulungan, Nunukan, dan Penajam Pasir Utara.
Gambar $5 a$ dan $5 b$ menunjukkan lokasi sektor pertambangan-penggalian yang merupakan sektor unggulan di Kaltim sebelum dan selama otda berlangsung. Kabupaten Pasir, Bulungan, dan Nunukan merupakan lokasi utama aktivitas pertambangan-penggalian pada 
(a) 1993-2000 (Sebelum Otda)

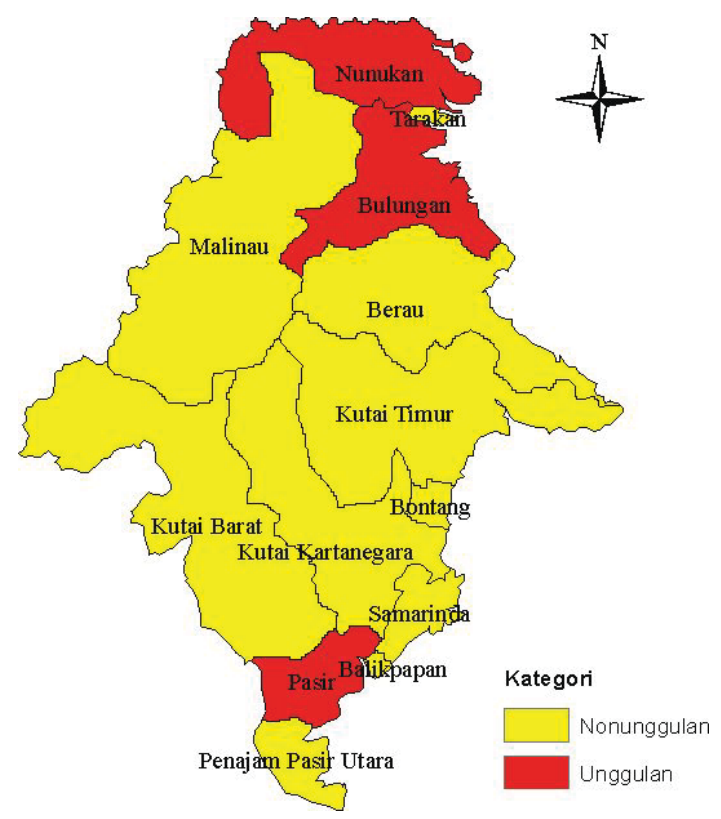

(b) 2001-2007 (Selama Otda)

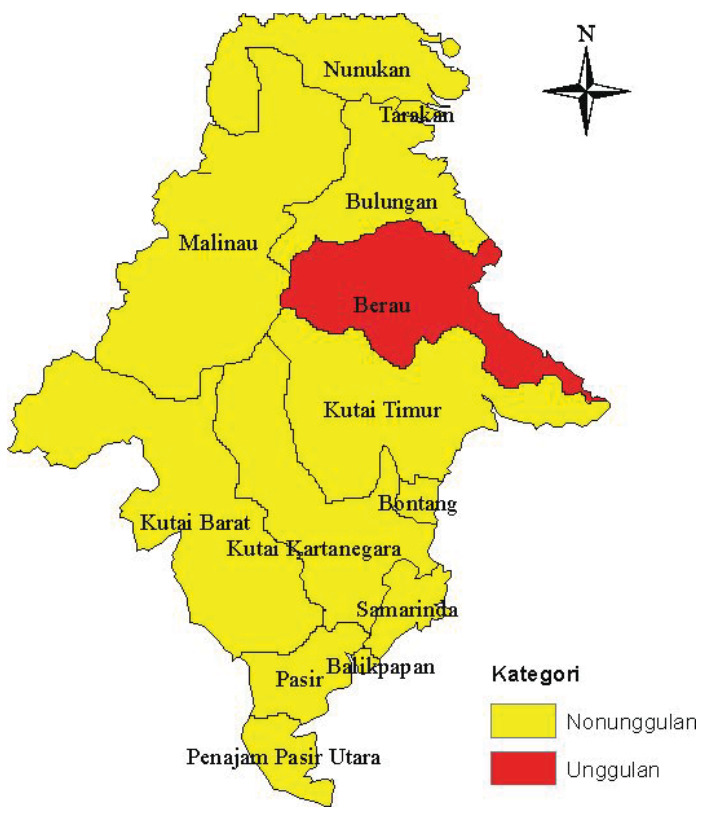

Sumber: Diolah dari BPS (2009)

Gambar 5. Lokasi Pertambangan dan Penggalian di Kaltim, 1993-2000 (Sebelum Otda) dan 2001-2007 (Selama Otda)

periode sebelum otda. Sementara pada periode otda, lokasi utama aktivitas pertambangan dan penggalian bertempat di Kabupaten Berau. Selama 1993-2000, rata-rata kontribusi sektor pertambangan dan penggalian terhadap PDRB Migas di tiga kabupaten tersebut secara berturut-turut adalah 21,6 persen, 17,1 persen, dan 22 persen. Sementara itu, rata-rata kontribusi sektor pertambangan dan penggalian terhadap PDRB migas di Kabupaten Berau selama 20012007 adalah 37,6 persen (BPS, berbagai tahun).

Gambar $6 a$ dan $6 b$ menunjukkan lokasi subsektor unggulan di Kaltim sebelum dan selama otda berlangsung. Hasil analisis dengan SSLQ dan DSLQ menunjukkan bahwa subsektor unggulan di Kaltim pada periode sebelum otda adalah kehutanan, migas, dan perdagangan besar-eceran. Lokasi utama aktivitas subsektor kehutanan berada di Kabupaten Kutai Barat dan Nunukan, dengan rata-rata kontribusi terhadap PDRB migas berturut-turut sebesar 13,8 persen dan 40 persen. Aktivitas migas terutama berlokasi di Kabupaten Nunukan, dengan ratarata kotribusi terhadap PDRB migas sebesar
21,5 persen. Sedangkan, aktivitas perdagangan besar-eceran terutama berlokasi di Kota Balikpapan, Samarinda, Tarakan, dan Kabupaten Pasir, dengan rata-rata kontribusi terhadap PDRB migas berturut-turut sebesar 15,4 persen, 24,4 persen, 41 persen, dan 16,2 persen.

Hasil analisis dengan SSLQ dan DSLQ menunjukkan bahwa subsektor unggulan di Kaltim sejak otda berlangsung adalah migas, pertambangan tanpa migas, dan industri migas. Subsektor-subsektor usaha yang masuk dalam kategori unggulan selama otda tersebut sebagian besar merupakan bagian sektor primer yang secara alami disediakan oleh alam dengan minimnya unsur campur tangan (olah) manusia. Berbeda dengan periode selama otda, subsektor-subsektor usaha yang tergolong unggulan pada periode sebelum otda terdiri atas kehutanan, migas, dan perdagangan besar-eceran, di mana aktivitas usaha unggulannya telah cukup terdiversifikasi, sesuai dengan tujuan Kaltim ke depan yakni sedini mungkin mempersiapkan "lokomotif ekonomi" baru yang berbasis sumberdaya terbaharui (renewable resources) yang 
(a) 1993-2000 (Sebelum Otda)
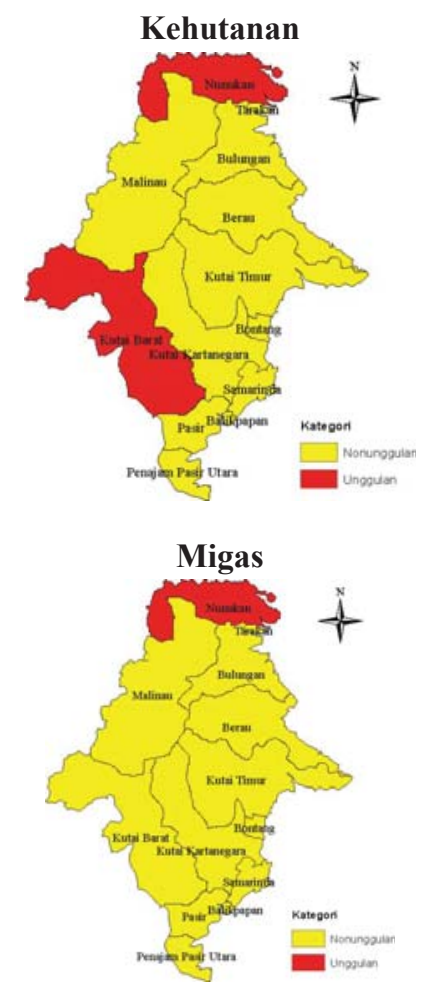

Perdagangan besar dan eceran

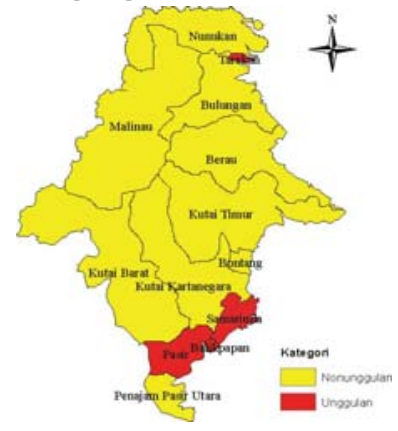

(b) 2001-2007 (Selama Otda)

Pertambangan tanpa migas*

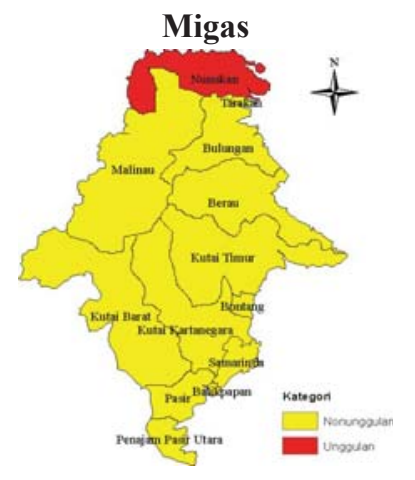

Industri migas

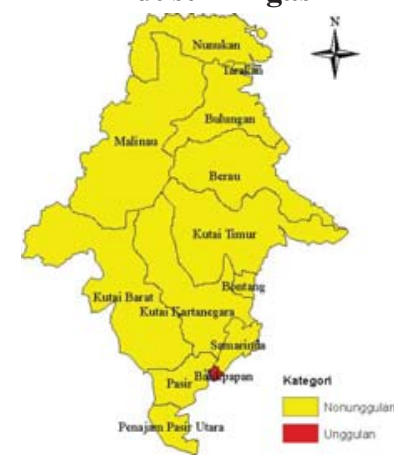

* Berlokasi di beberapa kabupaten/kota di mana pertambangan tanpa migas tergolong subsektor prospektif, yakni Kabupaten Pasir, Kutai Barat, Kutai Timur, dan Berau.

Sumber: Diolah dari BPS (2009)

\section{Gambar 6. Subsektor Unggulan dan Lokasinya di Kaltim}

potensial yakni agribisnis dalam arti luas. Bagaimanapun, tambang dan migas sebagai sumberdaya tak terbaharui (nonrenewable resources) suatu saat pasti akan habis (Kuncoro (ed.), 2008: 71).

Berdasarkan analisis dengan SSLQ dan DSLQ, tidak ada satu kabupaten/kota yang secara eksplisit menjadi lokasi utama subsektor pertambangan tanpa migas. Unggulnya pertambangan tanpa migas di Kaltim disebabkan oleh akumulasi kontribusi yang besar dari beberapa kabupaten di Kaltim. Pertambangan tanpa migas di beberapa kabupaten tersebut tergolong sebagai subsektor prospektif. Bebera- 
pa kabupaten tersebut adalah Pasir, Kutai Barat, Kutai Timur, dan Berau. Rata-rata kontribusi pertambangan tanpa migas terhadap PDRB migas di kabupaten-kabupaten tersebut selama 2001-2007 secara berturut-turut adalah 43,1 persen, 40,4 persen, 81,9 persen, dan 37,5 persen. Aktivitas subsektor migas terutama berlokasi di Kabupaten Nunukan, tidak berbeda dengan periode sebelum otda, dengan rata-rata kontribusi terhadap PDRB migas sebesar 34,2 persen. Sementara itu, aktivitas industri migas terutama berlokasi di Kota Balikpapan, dengan rata-rata kotribusi terhadap PDRB migas sebesar 43,6 persen.

\section{Mengapa Tidak Terjadi Transformasi Struktural di Kaltim?}

Seberapa jauh hubungan antara perubahan struktural dengan pertumbuhan PDRB per kapita Kaltim dianalisis dengan metodologi yang dirintis oleh Hill, et al. (2009). Hubungan antara tingkat pertumbuhan PDRB per kapita dengan kecepatan perubahan struktural (indeks perubahan struktural) sebelum dan selama otda berlangsung di Kaltim ditunjukkan dalam Gambar 7 dan Gambar 8.

Gambar 7 yang menggunakan data 9 sektor dan Gambar 8 yang menggunakan data 26 subsektor sama-sama menunjukkan bahwa terdapat korelasi antara tingkat pertumbuhan PDRB per kapita dengan perubahan struktural. Perubahan struktural tercepat terjadi di beberapa kabupaten, yakni Pasir (Psr), Berau (Bru), Nunukan (Nnk), Kutai Timur, Malinau (Mln), dan Bulungan (Blg). Keenam kabupaten tersebut sama-sama merupakan kabupaten yang kaya akan sumber daya alam (resource rich regions), terutama pertambangan-penggalian. Dari Gambar 7 dan Gambar 8 tampak bahwa hanya Kabupaten Pasir, Nunukan, dan Malinau yang di samping mengalami perubahan struktural yang cepat juga mengalami tingkat pertumbuhan PDRB per kapita yang tinggi. Kutai Barat (Kbr) dan Kota Samarinda (Smr) hanya menikmati tingkat pertumbuhan PDRB per kapita yang tinggi. Sementara itu, Berau dan Bulungan hanya menikmati tingkat perubahan struktural yang tinggi.

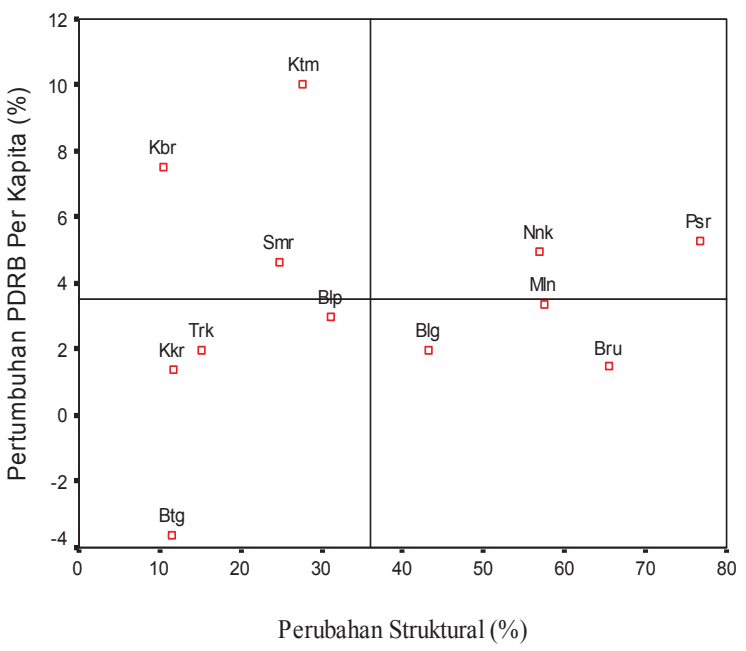

Catatan:

Perubahan Struktural $=\Sigma_{\mathrm{i}} \mid$ share $_{\mathrm{i}, 01}-$ share $_{\mathrm{i}, 00} \mid ; \mathrm{yi}$

$=\{$ pertanian, industri manufaktur, jasa $\}$

share $_{\mathrm{i}, 01}=$ rata-rata pangsa sektor 2001-2007; share $_{\mathrm{i}, 00}=$

rata-rata pangsa sektor 1993-2000

Sumber: Diolah dari BPS (2009); BPS Provinsi Kaltim (2008)
Gambar 7. Perubahan Struktural Sektoral dan Pertumbuhan di Kaltim Tahun 1993-2000 (Sebelum Otda) Versus 2001-2007 (Selama Otda)

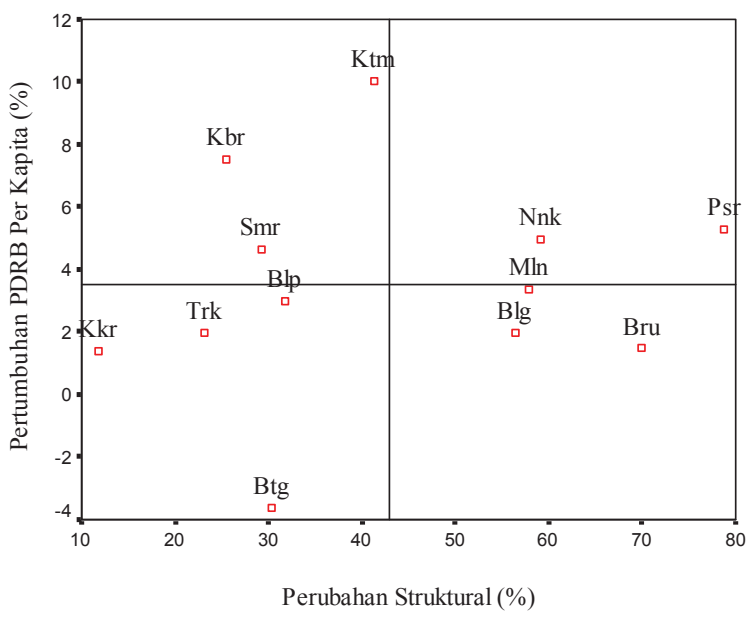

Catatan:

Perubahan Struktural $=\Sigma_{\mathrm{i}} \mid$ share $_{\mathrm{i}, 01}-$ share $_{\mathrm{i}, 00} \mid ; \mathrm{yi}=\{26$ subsektor ekonomi\}

Sumber: Diolah dari BPS (2009); BPS Provinsi Kaltim (2008)

Gambar 8. Perubahan Struktural Subsektoral dan Pertumbuhan di Kaltim Tahun 1993-2000 (Sebelum Otda) Versus 2001-2007 (Selama Otda) 


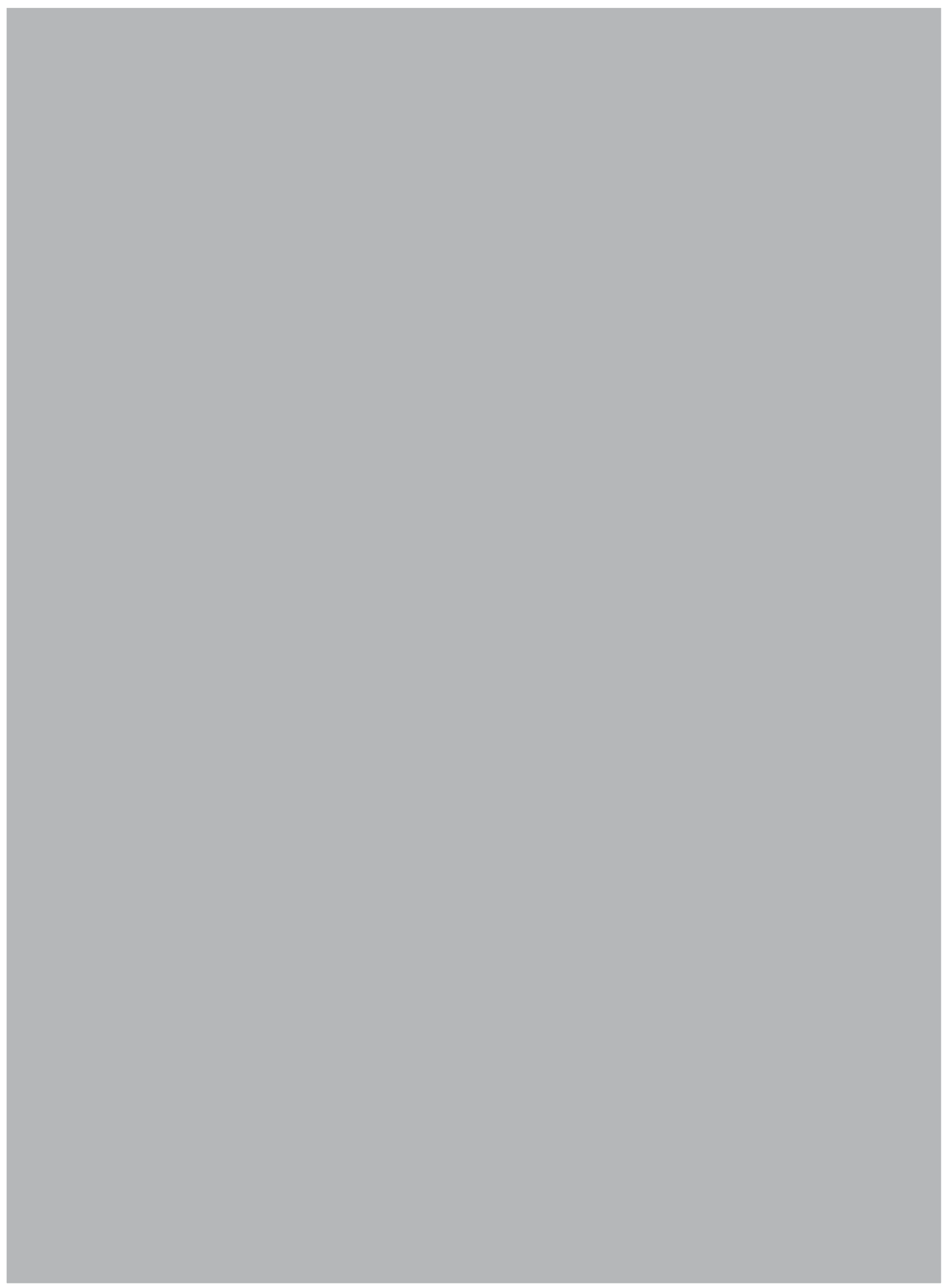


tersier; (3) menurunnya pangsa sektor tersier bersamaan dengan meningkatnya pangsa sektor primer dan sekunder; dan (4) semakin meningkatnya pangsa sektor sekunder bersamaan dengan terus menurunnya pangsa sektor primer dan tersier. Kabupaten yang mengalami pola perkembangan pertama adalah Kutai Barat, Malinau, Bulungan, dan Nunukan. Kota yang mengalami pola perkembangan kedua adalah Balikpapan dan Samarinda. Kota yang mengalami pola perkembangan ketiga adalah Tarakan. Sedangkan, kota yang mengalami pola perkembangan keempat adalah Bontang.

Kaltim merupakan provinsi yang kaya sumberdaya alam, khususnya pertambanganpenggalian. Digantikannya peranan sektor sekunder oleh sektor primer juga diikuti dengan meningkatnya pangsa sektor pertambanganpenggalian dan menurunnya pangsa sektor pertanian-kehutanan. Peningkatan peran sektor pertambangan-penggalian dalam perekonomian Provinsi Kaltim sangat terlihat pada periode otda (lihat Tabel 11). Dari 12 kabupaten/kota yang terdapat di Kaltim, hanya 4 kota yang tidak memiliki sumberdaya alam melimpah, yakni Balikpapan, Samarinda, Tarakan, dan Bontang. Kendati demikian, industri pengolahan migas sangat dominan dalam perekonomian kota Bontang dan Balikpapan. Selama 1993-
2007, rata-rata pangsa industri pengolahan migas di Bontang dan Balikpapan berturut-turut sebesar 84,6 persen dan 46,8 persen. Dengan demikian, perekonomian Kaltim amat dikendalikan oleh sektor pertambangan-penggalian dan industri pengolahan yang terkait dengan aktivitas minyak dan gas.

Tabel 11 mempertegas hasil analisis yang ditunjukkan dalam Gambar 7 dan Gambar 8. Pasir, Berau, Nunukan, dan Malinau merupakan empat kabupaten di Kaltim yang mengalami tingkat perubahan struktural tercepat. Pangsa sektor pertambangan-penggalian di ketiga kabupaten pertama mengalami peningkatan yang sangat tinggi selama otda berlangsung. Pangsa pertambangan-penggalian di Pasir meningkat dari 21,6 persen sebelum otda menjadi 59,9 persen selama otda. Sementara itu, peningkatan yang terjadi di Berau dan Nunukan berturut-turut dari 10,5 persen menjadi 37,6 persen dan dari 22 persen menjadi 42,1 persen selama periode yang sama. Kabupaten/kota lain yang telah memiliki pangsa sektor pertambangan-penggalian atau pangsa industri pengolahan yang terkait pertambangan-penggalian yang besar pada periode sebelum otda umumnya memiliki tingkat perubahan struktural yang rendah. Adapun Malinau, indeks perubahan struktural yang tinggi lebih disebab-

Tabel 11. Pangsa Pertanian dan Pertambangan-Penggalian di Kaltim Menurut Kabupaten/Kota Sebelum (1993-2000) dan Selama Otda (2001-2007)

\begin{tabular}{lcccccc}
\hline \multirow{2}{*}{ Prov/Kab/Kota } & \multicolumn{3}{c}{ Pertanian-Kehutanan } & \multicolumn{3}{c}{ Pertambangan-Penggalian } \\
& Praotda & Otda & Perubahan & Praotda & Otda & Perubahan \\
\hline Prov. Kaltim & 8.27 & 6.74 & -18.54 & 30.90 & 37.67 & 21.90 \\
Kab. Pasir ${ }^{1}$ & 27.41 & 17.36 & -36.67 & 21.55 & 59.87 & 177.84 \\
Kab. Kutai Barat & 27.27 & 22.82 & -16.31 & 44.82 & 47.85 & 6.77 \\
Kab. Kutai Kartanegara & 9.57 & 7.45 & -22.14 & 77.08 & 82.18 & 6.61 \\
Kab. Kutai Timur & 11.53 & 4.99 & -56.73 & 71.41 & 85.18 & 19.28 \\
Kab. Berau & 32.08 & 23.08 & -28.05 & 10.46 & 37.61 & 259.58 \\
Kab. Malinau & 83.14 & 54.60 & -34.32 & 1.96 & 8.04 & 309.10 \\
Kab. Bulungan & 51.93 & 30.84 & -40.61 & 17.08 & 18.79 & 10.04 \\
Kab. Nunukan & 60.81 & 33.86 & -44.33 & 22.00 & 42.11 & 91.41 \\
Kota Balikpapan & 1.18 & 2.68 & 127.58 & 7.66 & 0.04 & -99.48 \\
Kota Samarinda & 1.48 & 2.27 & 53.44 & 1.92 & 5.23 & 173.07 \\
Kota Tarakan & 11.63 & 11.14 & -4.27 & 3.03 & 5.29 & 74.33 \\
Kota Bontang & 0.39 & 0.11 & -70.94 & 0.46 & 0.18 & -61.39 \\
Rata-rata ${ }^{2}$ & 26.54 & 17.60 & -14.45 & 23.29 & 32.70 & 80.60 \\
\hline Catatan: & \multicolumn{7}{c}{} & & & \\
1 Kab. Pasir terdiri atas Pasir dan Penajam Pasir Utara; & 2 merupakan rata-rata dari kabupaten/kota \\
Sumber: Diolah dari BPS (2009); BPS Kaltim (2008) & & & &
\end{tabular}




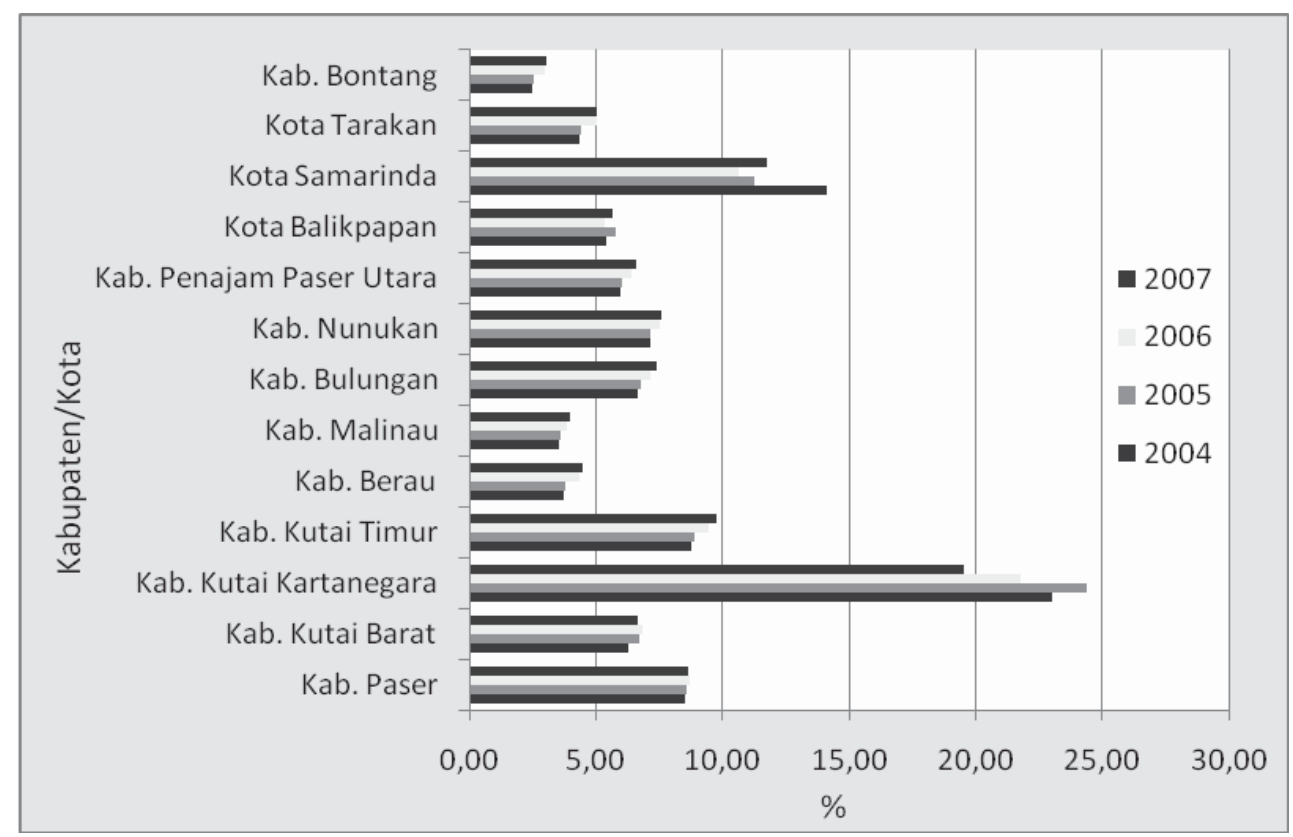

Sumber: Diolah dari BPS Kaltim (2008)

Gambar 9. Tingkat Kemiskinan Berdasarkan Kabupaten/Kota di Kaltim Tahun 2004-2007 (\%) 
2009 mengalami penurunan hingga hanya 3 kabupaten, yaitu Malinau, Kutai Barat, dan Nunukan (Kementerian Pembangunan Daerah Tertinggal, 2005 dan 2010). Kendati telah mengalami penurunan, masih adanya 3 kabupaten yang tergolong daerah tertinggal di Kaltim tetap merupakan prestasi buruk bagi Kaltim.

Salah satu masalah besar dalam pembangunan di Kaltim adalah besarnya persentase penduduk miskin. Kekayaan alam Kaltim yang melimpah, khususnya pertambangan-penggalian, ternyata belum mampu meningkatkan kesejahteraan seluruh rakyat Kaltim. Tentunya hal ini sangat ironis mengingat Kaltim adalah salah satu provinsi penyumbang terbesar dalam PDRB Indonesia. Gambar 9 menunjukkan tingkat kemiskinan menurut kabupaten/kota di Kaltim. Tingkat kemiskinan tertinggi, dengan persentase lebih dari 10 persen, terjadi di Kabupaten Kutai Kartanegara dan Kota Samarinda.

\section{SIMPULAN}

Simpulan utama yang dapat ditarik berdasarkan hasil analisis dalam artikel ini adalah: Pertama, penerapan otonomi daerah berpengaruh positif terhadap struktur pertumbuhan ekonomi dan tingkat PDRB per kapita kabupaten/kota di Kaltim. Kendati tingkat pertumbuhan ekonomi mengalami penurunan sedikit, rata-rata tingkat PDRB per kapita mengalami peningkatan yang cukup signifikan. Di samping itu, jumlah daerah yang tergolong daerah relatif tertinggal mengalami penurunan yang signifikan pascaotda. Kedua, pertambanganpenggalian tetap menjadi sektor unggulan di Kaltim baik sebelum maupun selama otda berlangsung. Subsektor unggulan di Kaltim terdiri atas kehutanan, minyak-gas bumi, pertambangan tanpa migas, industri migas, dan perdagangan besar-eceran. Hasil analisis menunjukkan bahwa tidak ada perubahan spesialisasi pada sektor unggulan di Kaltim, bahkan terjadi despesialisasi pada subsektor unggulan di Kaltim. Ketiga, transformasi struktural tidak terjadi dalam perekonomian Kaltim. Perekonomian Kaltim justru mengalami gejala deindustrialisasi. Tidak terjadinya transformasi struktural dalam perekonomian Kaltim bisa jadi karena Kaltim belum menerapkan strategi industrialisasi dalam perekonomiannya. Hasil analisis terhadap proses transformasi struktural di Kaltim ini, yang menunjukkan bahwa melimpahnya ketersediaan minyak dan gas serta dominannya sektor pertambangan-penggalian merupakan sebab tidak terjadinya industrialisasi, dapat dibuktikan juga pada provinsi/daerah lain yang memiliki karakter serupa yakni kaya sumberdaya alam, khususnya pertambanganpenggalian. Kaltim merupakan contoh daerah yang mengalami gejala growth without development.

Sebagai provinsi yang kaya sumberdaya alam, Kaltim memiliki potensi yang besar untuk berkembang dan maju. Namun, berbagai permasalahan mendasar yang masih ada dapat menjadi penghambat bagi kemajuan Kaltim jika tidak dapat diatasi dengan baik. Oleh karena itu, Kaltim harus mengerahkan seluruh sumberdaya yang dimiliki untuk memecahkan berbagai masalah pembangunan yang dihadapi. Masih banyaknya masalah pembangunan di Kaltim bisa jadi karena masih rendahnya pangsa Anggaran Pendapatan dan Belanja Daerah (APBD) yang dipakai untuk pelayanan publik. Salah satu penyebab rendahnya pelayanan publik adalah karena APBD masih probirokrasi dan tidak prorakyat. Hal tersebut tercermin dari alokasi belanja aparatur yang lebih tinggi daripada belanja rutin, terutama APBD kabupaten/kota.

\section{DAFTAR PUSTAKA}

Badan Pusat Statistik. 2010. Master Kabupaten 1993-2002.

http://www.bps.go.id/mstkab/mfkab_93_02.pd f Diakses 15 Juni.

Badan Pusat Statistik 2010. Master Kabupaten 2003-2009.

http://www.bps.go.id/mstkab/mfkab_03_09.pd f. Diakses 15 Juni.

Balassa, B. 1965. Trade Liberalization and 'Revealed' Comparative Advantage, The Manchester School of Economics and Social Studies 33(2): 99-123. 
Bank Indonesia 2008. Upaya Peningkatan Daya Saing Industri dalam Pasar Bebas. Proceeding Paper, Indonesian Debt Forum (IDF). Jakarta: Bank Indonesia.

Bendavid-Val, A. 1991. Regional and Local Economic Analysis for Practitioners (4th ed.). New York: Praeger.

Blakely, Edward J. 1989. Planning Local Economic Development: Theory and Practice, Sage Library of Social Research 168, Washington: Sage Publication.

Dalum, B., K. Laursen and G. Villumsen. 1998 Structural Change in OECD Export Specialization Patterns: De-specialization and 'stickiness, International Review of Applied Economics 12: 447-467.

Departemen Perindustrian. 2006. Membangun Daya Saing Industri dengan Basis Klaster dan Kompetensi Inti Daerah. Jakarta: Depperin.

Departemen Perindustrian. 2007. Peta Jalan Pengembangan Kompetensi Inti Industri Daerah. Jakarta: Departemen Perindustrian.

Hill, H. (Ed.). 1989. Unity and Diversity: Regional Economic Development in Indonesia since 1970. Singapore: Oxford University Press.

Hill, Hal, Budy P. Resosudarmo dan Yogi Vidyattama. 2009. Economic Geography of Indonesia: Location, Connectivity, and Resources. Reshaping Economic Geography in East Asia. Washington: The World Bank.

Kuncoro, Mudrajad. 2002. Analisis Spasial dan Regional: Studi Aglomerasi dan Kluster In- dustri Indonesia. Yogyakarta: UPP STIM YKPN.

Kuncoro, Mudrajad. 2004. Otonomi dan Pembangunan Daerah: Reformasi, Perencanaan, Strategi dan Peluang. Jakarta: Erlangga.

Kuncoro, Mudrajad. 2006. Ekonomika Pembangunan: Teori, Masalah, dan Kebijakan. Edisi ke-4. Yogyakarta: UPP STIM YKPN.

Kuncoro, Mudrajad. 2007. Ekonomika Industri Indonesia, Menuju Negara Industri Baru 2030. Yogyakarta: Andi Offset.

Kuncoro, Mudrajad. 2008. Expectation on Government Policy to Strengthen Industry Competitiveness. Published Proceeding Paper, Indonesian Debt Forum (IDF). Bank Indonesia.

Laursen, K. 1998. Revealed Comparative Advantage and the Alternatives as Measures of International Specialization, DRUID Working Paper. No 98-30. Danish Research Unit for Industrial Dynamics (DRUID).

Widodo, Tri. 2009. Dynamics of Trade Specialization: Two Competing Econometric Models. JEL No. F10, F14, F17.

Widodo, Tri. 2009. Comparative Advantage: Theory, Empirical Measures, and Case Studies. REBS Review of Economic and Business Studies, Issue April, 2009.

Wörz, J. 2005. Dynamic of Trade Specialization in Developed and Less Developed Countries, Emerging Markets Finance and Trade 41(3):92-2 